\title{
Taxonomic Study of Paracoccus denitrificans
}

\author{
TALAAT-H. NOKHAL AND HANS G. SCHLEGEL* \\ Institut für Mikrobiologie der Universität Göttingen, D-3400 Göttingen, Federal Republic of Germany
}

\begin{abstract}
Isolates of Paracoccus denitrificans were obtained from various habitats by enrichment in a mineral medium, using molecular hydrogen as the hydrogen donor and nitrate as the hydrogen acceptor. A total of 11 strains were compared with the following three reference strains: $P$. denitrificans Stanier $381^{\mathrm{T}}$ (type strain) $\left(=\operatorname{DSM} 65^{\mathrm{T}}=\right.$ ATCC $\left.17741^{\mathrm{T}}\right)$, Morris $(=\mathrm{DSM} 413=$ ATCC 19367), and Vogt (= DSM 415). A computer analysis based on 235 characters indicated that the strains clustered into subgroups. Deoxyribonucleic acid-deoxyribonucleic acid homology determinations confirmed this suggestion. A formal description of the species is presented, and the taxonomic position of $P$. denitrificans is discussed.
\end{abstract}

Paracoccus denitrificans (formerly known as Micrococcus denitrificans) was first isolated by Beijerinck and Minkman (5) and was reisolated as a bacterium that was capable of using molecular hydrogen in denitrification by Verhoeven et al. (56) and Vogt (57). Although this species has a guanine-plus-cytosine $(G+C)$ content similar to the $\mathrm{G}+\mathrm{C}$ contents of some members of Micrococcus, it differs from other species of Micrococcus as follows (40): (i) $P$. denitrificans forms rod-shaped cells in young cultures $(34,39,55$, 57); (ii) it is gram negative $(9,34,56,57)$; (iii) it has a cell wall peptidoglycan which contains a wide range of amino acids characteristic of gram-negative genera, and the cell wall contains diaminopimelic acid in place of the lysine characteristic of micrococci (4); and (iv) it contains ubiquinone as an electron carrier (46), which is characteristic of gram-negative bacteria. For these reasons a new genus, Paracoccus was created (9). The electron transport chain of $P$. denitrificans resembles the electron transport chain of the inner mitochondrial membrane more closely than the electron transport chain of any other bacterium (21). The hydrogenase of $P$. denitrificans strain Stanier $381^{\mathrm{T}}$ (type strain) has been isolated and characterized $(49,50)$, and the regulation of hydrogenase formation as a diagnostic character of the reference strains of $P$. denitrificans and of newly isolated strains has been studied (35).

Although $P$. denitrificans was isolated more than 70 years ago (5) and has been used in many investigations, its taxonomic position is still ill defined; the genus was placed with "genera of uncertain affiliation" (11) because only two strains were available for study and taxonomic data were lacking.

The objectives of this study were to isolate many new strains of $\boldsymbol{P}$. denitrificans, to deter- mine their main features, to compare them with the strains kept in culture collections, to evaluate their similarities and delineate them from other related bacteria, and to determine their taxonomic niche.

\section{MATERIALS AND METHODS}

Organisms. The bacterial strains which we studied are listed in Table 1 . A total of 11 strains, designated $\mathrm{N} 1$ through $\mathrm{N} 11$, were isolated after specific enrichment culture (24). Three strains of $P$. denitrificans (DSM 65 ${ }^{\mathrm{T}}$, DSM 413, and DSM 415) were obtained from the Deutsche Sammlung von Mikroorganismen (DSM), Göttingen, Federal Republic of Germany (7). Strains of other species (Table 2) were compared with respect to deoxyribonucleic acid (DNA) base composition and biochemical and physiological characteristics (Table 2). These reference strains were grown in nutrient broth (Difco Laboratories, Detroit, Mich.).

Growth conditions. Unless otherwise stated, media were prepared from a standard mineral base (SM) which contained (per liter of distilled water) $9.0 \mathrm{~g}$ of $\mathrm{NaH}_{2} \mathrm{PO}_{4} \cdot 12 \mathrm{H}_{2} \mathrm{O}, 1.5 \mathrm{~g}$ of $\mathrm{KH}_{2} \mathrm{PO}_{4}, 1.0 \mathrm{~g}$ of $\mathrm{NH}_{4} \mathrm{Cl}$, $0.2 \mathrm{~g}$ of $\mathrm{MgSO}_{4} \cdot 7 \mathrm{H}_{2} \mathrm{O}, 0.0012 \mathrm{~g}$ of $\mathrm{Fe}(\mathrm{III}) \mathrm{NH}_{4}$-citrate, and $0.0265 \mathrm{~g}$ of $\mathrm{CaCl}_{2} \cdot 2 \mathrm{H}_{2} \mathrm{O}(43) ; \mathrm{SM}$ also contained $10 \mathrm{ml}$ of trace element solution SL6 per liter of distilled water (37). For autotrophic growth the medium was supplemented with $0.05 \%$ (wt/vol) $\mathrm{NaHCO}_{3}$ (separately sterilized), and for heterotrophic growth the medium was supplemented with organic compounds as carbon and energy sources in concentrations ranging from $0.1 \%(\mathrm{wt} / \mathrm{vol})$ for organic acids and bases to $0.2 \%$ (wt/vol) for other compounds, unless otherwise indicated. For anaerobic growth, either autotrophically or heterotrophically, $1.0 \%$ (wt/vol) $\mathrm{KNO}_{3}\left(\right.$ or $\mathrm{KNO}_{2}$ ) was used as a terminal oxidant to substitute for free oxygen. Nutrient broth (Difco) was used as a nutritionally complex medium. If required, $1.7 \%(\mathrm{wt} / \mathrm{vol})$ agar (Difco) was added to solidify the media used. The final $\mathrm{pH}$ was adjusted to 7.1 , and the growth temperature was $30^{\circ} \mathrm{C}$. For heterotrophic growth, the liquid cultures were stirred magnetically or shaken under a continuous air stream; for autotrophic growth, gas 
TABLE 1. List of $P$. denitrificans strains studied ${ }^{a}$

\begin{tabular}{|c|c|c|c|c|}
\hline \multirow{2}{*}{ Strain } & \multirow{2}{*}{ Isolated from: } & \multicolumn{2}{|c|}{ Isolated by: } & \multirow{2}{*}{ Other designation(s) ${ }^{b}$} \\
\hline & & Worker(s) & Reference & \\
\hline Stanier $381^{\mathrm{T}}$ & Garden soil & $\begin{array}{l}\text { Beijerinck and } \\
\text { Minkman }\end{array}$ & 5 & $\operatorname{DSM} 65^{\mathrm{T}}$, ATCC $17741^{\mathrm{T}} \mathrm{c}$ \\
\hline Morris 5 & Garden soil & Verhoeven et al. & 56 & $\begin{array}{l}\text { DSM 413, ATCC 19367, CCM 982, } \\
\text { NCIB } 8944\end{array}$ \\
\hline Vogt 11 & Arable soil & Vogt & 57 & DSM 415, CCM 1396, NCIB 9722 \\
\hline N1 & Sewage & Nokhal & This study & DSM 1403 \\
\hline N2 & Sewage & Nokhal & This study & \\
\hline N3 & Sewage & Nokhal & This study & \\
\hline N4 & Sludge & Nokhal & This study & DSM 1404 \\
\hline N5 & Meadow soil & Nokhal & This study & DSM 1405 \\
\hline N6 & Meadow soil & Nokhal & This study & \\
\hline N7 & Horse manure & Nokhal & This study & DSM 1406 \\
\hline N8 & Canal mud & Nokhal & This study & \\
\hline N9 & Well mud & Nokhal & This study & \\
\hline N10 & Cow dung & Nokhal & This study & DSM 1407 \\
\hline N11 & Field soil & Nokhal & This study & DSM 1408 \\
\hline
\end{tabular}

${ }^{a}$ The 11 new isolates (strains N1 through N11) were identified as $P$. denitrificans on the basis of an enrichment procedure, as well as their morphological, nutritional, physiological, and biochemical characteristics (this study).

${ }^{b}$ ATCC, American Type Culture Collection, Rockville, Md.; CCM, Czechoslovak Collection of Microorganisms, J. E. Purkyne University, Brno, Czechoslovakia; DSM, Deutsche Sammlung von Mikroorganismen, Göttingen, Federal Republic of Germany; NCIB, National Collection of Industrial Bacteria, Torry Research Station, Aberdeen, Scotland.

${ }^{c}$ See reference 9 .

mixtures containing $\mathrm{H}_{2}, \mathrm{CO}_{2}$, and $\mathrm{O}_{2}(80: 10: 10$, vol/ vol) and $\mathrm{H}_{2}$ and $\mathrm{CO}_{2}(85: 15, \mathrm{vol} / \mathrm{vol})$ were used for aerobic growth and anaerobic growth, respectively.
Growth and cell yield. Turbidity was determined at $436 \mathrm{~nm}$ (light path, $1 \mathrm{~cm}$ ) with a Bausch \& Lomb Spectronic 70 photometer. The protein contents of

TABLE 2. List of bacterial strains used as test organisms

$\begin{array}{cc}\text { Species } & \text { Strain }^{a} \\ \text { Bacillus subtilis } & \text { ATCC } 6051^{\mathrm{T}}\left(\mathrm{DSM} 10^{\mathrm{T}}\right)\end{array}$

Enterobacter aerogenes $\quad$ ATCC $13048^{\mathrm{T}}\left(\mathrm{DSM} 30053^{\mathrm{T}}\right)$

Escherichia coli

Proteus vulgaris

Pseudomonas aeruginosa

Xanthomonas pelargonii
$\operatorname{ATCC} 11775^{\mathrm{T}}\left(\mathrm{DSM} 30083^{\mathrm{T}}\right)$

ATCC $13315^{\mathrm{T}}\left(\right.$ DSM $\left.30118^{\mathrm{T}}\right)$

ATCC $10145^{\mathrm{T}}\left(\mathrm{DSM} 50071^{\mathrm{T}}\right.$, ICPB $2523^{\mathrm{T}}$ )

DSM 50857 (ICPB P121) Controlled tests

Catalase activity, Voges-Proskauer reaction, citrate utilization, starch hydrolysis, casein digestion, alkalinization and reduction of litmus milk with casein digestion

Malonate utilization, esculin hydrolysis, lysine and ornithine decarboxylases, oxidative-versusfermentative test (aerogenic fermentation of glucose, lactose, and sucrose).

Acid reaction in litmus milk, methyl red reaction, indole production

Urease activity, gelatin liquefaction, $\mathrm{H}_{2} \mathrm{~S}$ production, growth in $\mathrm{KCN}$, phenylalanine deamination, no change of litmus milk

Arginine dehydrolase, oxidase reaction, oxidative-versusfermentative test (oxidizer), Tween 80 hydrolysis

Determination of both DNA base composition and molecular weight of bacterial genome DNA

\footnotetext{
${ }^{a}$ ATCC, American Type Culture Collection, Rockville, Md.; DSM, Deutsche Sammlung von Mikroorganismen, Göttingen, Federal Republic of Germany; ICPB, International Collection of Phytopathogenic Bacteria, Davis, Calif.
} 
whole-cell suspensions were estimated by the biuret method after alkaline hydrolysis of cells, as described by Schmidt et al. (44). Determination of cell dry weight was carried out on membrane filters (pore size, 0.2 $\mu \mathrm{m}$; Sartorius, Göttingen, Federal Republic of Germany) after drying at $80^{\circ} \mathrm{C}$ for 2 days. Samples from various stages of growth were centrifuged at 10,000 $\times$ $g$ for $10 \mathrm{~min}$, washed twice in $0.067 \mathrm{M}$ potassium phosphate buffer ( $\mathrm{pH} 7.0)$, resuspended in the same buffer to give final protein concentrations of about 10 to $20 \mathrm{mg} / \mathrm{ml}$, and stored at $-20^{\circ} \mathrm{C}$ for enzyme assays.

Enrichment, isolation, and purification of new strains. A total of 30 samples of soil, river mud, humus, sewage, and sludge collected from various places in and around Göttingen, Federal Republic of Germany, were used as inocula. Enrichment cultures were started by inoculating individual $100-\mathrm{ml}$ Erlenmeyer flasks containing $10 \mathrm{ml}$ of SM medium supplemented with nitrate with a sample (about $0.5 \mathrm{~g}$ ). Cultures were incubated under an atmosphere containing $\mathrm{H}_{2}$ and $\mathrm{CO}_{2}(85: 15$, vol/vol) in anaerobic jars without agitation. After 10 serial subcultures samples were plated onto agar, and pure cultures were isolated.

Maintenance of strains. Stock cultures were maintained as slants at $4^{\circ} \mathrm{C}$ under air. Autotrophically growing cultures were transferred every 3 to 6 months. In addition, all strains were kept on nutrient agar and transferred monthly. Lyophilized samples in $20 \%$ (wt/vol) skim milk were prepared for long-term storage.

Colony properties and growth appearance in liquid media. Colonies were described from 3-day aerobic growth on nutrient agar and autotrophic growth under $\mathrm{H}_{2}-\mathrm{CO}_{2}-\mathrm{O}_{2}$ at $30^{\circ} \mathrm{C}$. Growth responses in liquid media (nutrient broth, glucose, fructose, glycerol, acetate, pyruvate, lactate, succinate, gluconate) agitated on a rotatory shaker at $30^{\circ} \mathrm{C}$ were determined after $48 \mathrm{~h}$.

Cytological observations. Cells from both exponential and stationary growth phases in lactate broth were used to determine morphological properties. Motility was studied by light microscopic examination of hanging drop preparations of 24-h cultures in nutrient broth. All staining was performed by the methods of Cowan (8). Poly- $\beta$-hydroxybutyric acid granules were recognized by their typical appearance and by their solubility in chloroform and insolubility in ether. Quantitative determinations of poly- $\beta$-hydroxybutyric acid were made by the procedure of Jüttner et al. (22). Polyphosphate granules were detected by electron microscopy and confirmed by Neisser stain (8). Pigment production was tested by cultivation of slants on both nutrient agar and lactate agar slopes illuminated for 10 days by a $40-W$ incandescent lamp from a distance of $50 \mathrm{~cm}$.

Growth and nutritional screening. For assays of utilization of organic compounds as sole carbon and energy sources, each strain was tested for its ability to grow in the presence of 100 different compounds by using the replica technique described by Stanier et al. (54); we used the basal medium supplemented with $0.2 \%(\mathrm{wt} / \mathrm{vol})$ carbohydrate, $0.025 \%(\mathrm{wt} / \mathrm{vol}) \mathrm{phenol}$, or one of the other compounds at a concentration of $0.1 \%$ (wt/vol) and solidified by $1.7 \%$ agar (Difco). Each test series included a control plate lacking the carbon source. Inoculated test plates were incubated under air and scored visually after 2, 4, and 7 days. Strains with questionable growth on plates were fur- ther examined in liquid media, where the growth yield was determined turbidimetrically. Utilization of waterinsoluble hydrocarbons was determined in liquid basal medium as described by Stanier et al. (54). The utilization of nitrogen sources was determined in the same manner as the utilization of carbon sources. Growth requirements were examined in basal medium supplemented with fructose, and growth was followed turbidimetrically.

Biochemical and physiological tests. Growth parameters were determined as described below. (i) The temperature range for growth was determined on nutrient agar. The optimum temperature was estimated in $\mathrm{SM}$ medium containing lactate. (ii) $\mathrm{The} \mathrm{pH}$ growth range and the $\mathrm{pH}$ optimum were determined in SM medium containing lactate. (iii) Relationships to oxygen were estimated by the method of Hugh and Leifson (18), and tolerance to oxygen tension was evaluated as indicated below (see Table 7). (iv) Tolerance to sodium chloride was estimated as described below (see Table 7). Indole production from tryptophan was tested by using the modification of Gore (51). Urea hydrolysis was tested by the National Collection of Type Cultures micromethod (8), and decarboxylation of L-amino acids (arginine, lysine, ornithine) was estimated by both the Moeller method and the Falkow method (8). The hydrolysis of arginine was estimated as described by Holding and Collee (17). The production of acid, acetoin, or 2,3-butanediol was investigated as described by Skerman (51). The type of aromatic ring cleavage was tested by the method of Hosokawa, as described by Stanier et al. (54), using $p$ - or $m$-hydroxybenzoate as the growth substrate. Accumulated $\beta$-keto acid ( $\beta$-ketoadipate) was detected by the Rothera reaction (17). The type of nitrate reduction under anaerobic growth conditions was investigated in both autotrophic and heterotrophic cultures in media containing $1.0 \%$ (wt/vol) $\mathrm{KNO}_{3}$. For autotrophic denitrification, $20-\mathrm{ml}$ portions of SM medium containing bicarbonate and nitrate in $100-\mathrm{ml}$ Erlenmeyer flasks were inoculated and incubated for 4 days under $\mathrm{H}_{2}-\mathrm{CO}_{2}(85: 15$, vol/vol). Heterotrophic denitrification tests were carried out as described by Stanier et al. (54). The presence of nitrite was estimated by using sulfanilic acid and $\alpha$-naphthylamine. Residual nitrate was determined by adding zinc to nitritenegative cultures.

Extracellular enzymes. All tests were performed and interpreted by using the methods of Holding and Collee (17), except that the test for poly- $\beta$-hydroxybutyrate depolymerase was carried out as described by Stanier et al. (54). Phospholipases were estimated by using egg yolk agar. Lipases were estimated by determining the decomposition of Tween 80 , Tween 60 , and Tween 40, using the method of Sierra (48). Proteinases were estimated by their proteolytic activities, which caused clear zones around colonies grown on milk agar or casein agar; gelatinase activity was determined by the method of Frazier, using $30 \%$ trichloroacetic acid as a substitute for acid mercuric chloride and the method of Pitt and Dey (38). Amylase activity on starch agar was detected with iodine solution. Cellulase activity was tested by using the method of Skinner (52).

Enzymes characteristic of major metabolic pathways. (i) Preparation of cell-free extracts. Thawed cell suspensions were disintegrated by single passages 
through a precooled French press (American Instruments Inc., Silver Spring, Md.) at $147 \mathrm{MPa}$, and unbroken cells and cell debris were removed by centrifugation at $10,000 \times g$ for $20 \mathrm{~min}$ at $4^{\circ} \mathrm{C}$. The resulting supernatant was referred to as the crude extract. The extract was then centrifuged at $140,000 \times$ $g$ for $90 \mathrm{~min}$ at $4^{\circ} \mathrm{C}$ to obtain the soluble fraction and membrane sediment. The membrane sediment was suspended in approximately 5 volumes of $50 \mathrm{mM}$ potassium phosphate buffer $(\mathrm{pH} 7.0)$ and homogenized with a Potter-Elvehjem homogenizer. All extracts were kept at $0^{\circ} \mathrm{C}$.

(ii) Determination of protein. The protein contents of cell-free extracts were determined by the method of Lowry et al. (31).

(iii) Enzyme assays. All enzyme assays were carried out in cuvettes (light path, $1 \mathrm{~cm}$ ) at $25^{\circ} \mathrm{C}$ by measuring the change in absorbance with a Zeiss model PM4 spectrophotometer linked to a transmission converter and recorder. The specific enzyme activities are expressed as milliunits per milligram of protein (units per gram of protein); $1 \mathrm{U}$ of enzyme activity was defined as the amount which converted $1 \mu \mathrm{mol}$ of substrate or formed $1 \mu \mathrm{mol}$ of product(s) per min.

Ribulosebisphosphate carboxylase (EC 4.1.1.39) activity was measured by ribulosebisphosphate-dependent incorporation of ${ }^{14} \mathrm{CO}_{2}$ into an acid-stable product, as described by Bowien et al. (6), and phosphoribulokinase (EC 2.7.1.19) activity was determined by the method of Abdelal and Schlegel (1), with slight modifications (the final concentration of reduced nicotinamide adenine dinucleotide was $1.0 \mathrm{mM}$ and the final concentration of ribulose 5-phosphate was 1.5 $\mathrm{mM}$ ). Membrane-bound hydrogenase activity was determined by reduction of methylene blue in the presence of molecular hydrogen, as described by Schink and Schlegel (42), and the reduction of oxidized nicotinamide adenine dinucleotide by soluble hydrogenase (EC 1.12.1.2) was determined by the method of Schneider and Schlegel (45). The activity of the Entner-Doudoroff system (phosphogluconate dehydratase [EC 4.2.1.12] plus phospho-2-keto-3-deoxygluconate aldolase [EC 4.1.2.14]) was estimated by the method of Gottschalk et al. (16). Malate dehydrogenase (EC 1.1.1.37) and reduced nicotinamide adenine dinucleotide oxidase (EC 1.6.99.3) were measured as described by Aggag and Schlegel (2).

Respiratory enzymes. Cytochrome difference spectra were determined with a Zeiss model DM 21 spectrophotometer. Samples were reduced and oxidized by solid dithionite and ferricyanide, respectively. Extraction and determination of quinones were done by the method of Kröger et al. (28). The activities of the terminal respiratory enzymes cytochrome oxidase (EC 1.9.3.1) and catalase (EC 1.11.1.6) were estimated as described by Kovacs (27) and Cowan (8), respectively.

Other tests. Growth with thiosulfate as the energy source was conducted in SM medium containing bicarbonate and $1.0 \%(\mathrm{wt} / \mathrm{vol}) \mathrm{Na}_{2} \mathrm{~S}_{2} \mathrm{O}_{3}$, and the inoculated cultures were incubated under a gas mixture containing $\mathrm{CO}_{2}, \mathrm{O}_{2}$, and $\mathrm{N}_{2}(10: 10: 80, \mathrm{vol} / \mathrm{vol})$ for up to 1 month. Hydrogen sulfide production was tested by cultivating cells on slopes of triple sugar iron agar, using the method of Cowan (8). The litmus milk reaction was carried out and interpreted by the method of Holding and Collee (17).

Susceptibility to inhibitors and antibiotics. The ability to grow in Moeller $\mathrm{KCN}$ broth was examined as described by Skerman (51). Antibiotic susceptibilities were determined by using a modified agar diffusion test; fructose agar plates were layered with $3 \mathrm{ml}$ of soft agar inoculated with $0.5 \mathrm{ml}$ of a 12-h-old culture. Four different susceptibility disks (Oxoid Ltd., London, England) were placed on each plate, and the diameters of the inhibition zones were measured after $48 \mathrm{~h}$ of incubation at $30^{\circ} \mathrm{C}$.

DNA relationships. Isolation and purification of bacterial DNAs and determinations of both DNA-DNA homology and molecular weights of bacterial genome DNAs were performed as described by Auling et al. (3). DNA base composition $(G+C$ content) was estimated by the thermal denaturation method of Mandel and Marmur (32), using $0.1 \times$ SSC $(1 \times$ SSC is $0.15 \mathrm{M}$ $\mathrm{NaCl}$ plus $0.015 \mathrm{M}$ sodium citrate). The midpoint of thermal denaturation of DNA $\left(T_{m}\right)$ was determined graphically after correction of absorbance values for thermal solvent expansion. The $\mathrm{G}+\mathrm{C}$ content (in moles percent) was calculated from the following equation: $\mathrm{G}+\mathrm{C}=2.08 T_{m}-106.4$, based on thermal denaturation in $0.1 \times$ SSC (36).

Computer analysis. For calculations of similarities among the strains studied, the similarity coefficient of Jaccard $(19,53)$ and the product-moment correlation coefficient, as modified for binary data (41), were used. A similarity matrix cluster was formed by complete linkage (30). Computer analysis was performed by using the algorithms of Wishart (41) and a Univac model 1108 computer (Gesellschaft für wissenschaftliche Datenverarbeitung, Göttingen, Federal Republic of Germany).

Chemicals. The polymer granules of poly- $\beta$-hydroxybutyric acid were extracted from Alcaligenes eutrophus H16. All other chemicals were of analytical grade and were commercially available.

\section{RESULTS}

About 400 bacterial isolates were obtained by specific enrichment to select strains of $P$. denitrificans (i.e., only those strains which grew anaerobically with molecular hydrogen as the energy source, $\mathrm{CO}_{2}$ as the carbon source, and nitrate or nitrite as the electron acceptor). Robust strains, which survived for 1 year at $4^{\circ} \mathrm{C}$ as autotrophic slants under air, were characterized and compared with the strains of $P$. denitrificans that had been kept in culture collections for many years (Table 1 ).

All strains studied showed considerable conformity in cultural, morphological, ultrastructural, biochemical, and physiological properties.

Cytology. All strains were short rods (coccobacilli), and generally the cells were shorter in stationary growth phases than during exponential growth. The average dimensions were 0.6 by $0.85 \mu \mathrm{m}$ and 0.8 by $1.2 \mu \mathrm{m}$ in stationary and exponential growth phases, respectively (Fig. 1a and b). Cell division was by binary transverse fission. Flagella or pili were not found in any strain, and light microscopic preparations confirmed that the cells were immobile. The cells were covered with a fibrous material which 


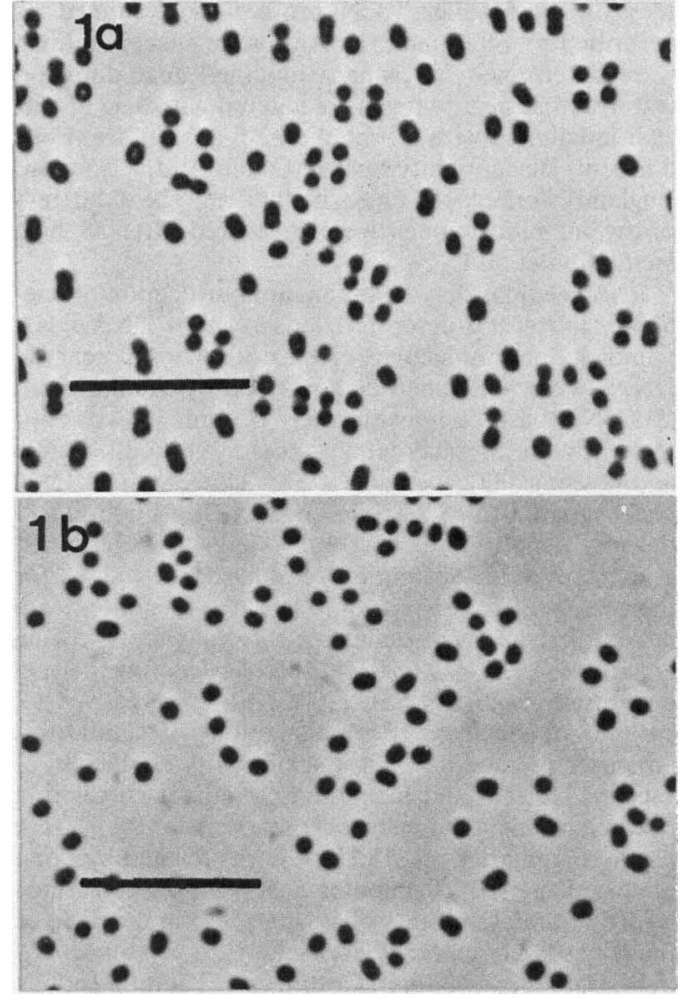

FIG. 1. Light microscopic phase-contrast micrographs of strain N4 (= DSM 1404) cells. (a) Cells in exponential growth phase. (b) Cells in stationary growth phase. Bar $=10 \mu \mathrm{m}$. S.381, Stanier $381^{\mathrm{T}}$; Vogt, Vogt 11; Morris, Morris 5.

showed a positive reaction with Ruthenium red, indicating the presence of large amounts of extracellular polyanions and acidic mucosubstances (34). All strains were gram-negative, and the cell wall fine structures were typical for gram-negative bacteria. Poly- $\beta$-hydroxybutyric acid was the main storage material, and its level ranged between 3 and $30 \%$ of the cell dry weight, depending on the growth substrate and conditions; in addition, polyphosphate and glycogenlike material were detected (34). All strains failed to produce pigment or endospores under various cultural growth conditions, and none was acid fast.

Cultural properties. Surface colonies of $P$. denitrificans on nutrient agar were circular, 2 to $4 \mathrm{~mm}$ in diameter, smooth or finely granulated, entire or undulate, convex or umbonate, creamy or faintly brown, and translucent with a soft consistency. On nitrogen-limited media the colonies were white and opaque. Liquid cultures were turbid with no pellicle. Old cultures tended to become brownish, but cultures of strain Stanier $381^{\mathrm{T}}$ turned pinkish, especially under low oxygen tensions.
Growth and nutritional screening. Of 100 organic compounds tested as sole carbon and energy sources for heterotrophic growth, only 41 were utilized universally, and 28 substrates could not be used by any strain (Table 3 ). The remaining 31 compounds were utilized by 1 or more of the 14 strains tested (Table 4). Cultures from mutant clones grew on some additional substrates, presumably due to altered permeability $(15,23,47)$. Molecular hydrogen but not carbon monoxide, methane, propane, ferrous iron, elemental sulfur, or reduced sulfur compounds served as an electron donor for growth and $\mathrm{CO}_{2}$ fixation at $\mathrm{pH}$ 7.0.

Of 14 nitrogenous compounds and molecular nitrogen tested as nitrogen sources in defined media, L-alanine, L-arginine, L-phenylalanine, Lproline, urea, ammonium chloride, and potassium nitrate were universal nitrogen sources. None of the 14 strains tested could grow with molecular nitrogen. Seven other compounds were used by one or more of the strains (Table 5).

None of the strains needed additional growth factors when they were grown heterotrophically or autotrophically with oxygen, although L-arginine, L-phenylalanine, and L-proline improved growth. This effect suggests that the nitrogen in these compounds is more readily available than the nitrogen in ammonium chloride. Yeast autolysate stimulated the growth of some strains (Table 6).

Biochemical and physiological features. The rate of growth in mineral medium containing lactate was maximum at $36^{\circ} \mathrm{C}$. Growth occurred at 10 and $40^{\circ} \mathrm{C}$ but not at 5 or $41^{\circ} \mathrm{C}$. Growth occurred at $\mathrm{pH}$ values ranging from 6.0 to 10 but not below pH 5.0 or above $\mathrm{pH} 11$; growth was optimal at pH 7.6. Metabolism was always respiratory and never fermentative. All strains failed to grow anaerobically unless nitrate or nitrite was added. Table 7 shows tolerance to oxygen tension under autotrophic growth conditions. All strains could grow well in nutrient broth containing from 0 to $3 \%(\mathrm{wt} / \mathrm{vol})$ sodium chloride; some strains exhibited a higher salt tolerance (Table 7). The methyl red test was negative throughout. All strains failed to grow on benzoate or L-tryptophan, but all could cleave either $m$ - or $p$-hydroxybenzoate via protocatechuate (ortho cleavage). The enzyme system was inducible; cells grown on nutrient broth gave negative reactions. Only strain N9 failed to grow on any of the aromatic compounds tested. Under anaerobic conditions nitrate was reduced to $\mathrm{N}_{2}$. Indole was produced from tryptophan. Urease activity, decarboxylation of $\mathrm{L}$-amino acids (arginine, lysine, ornithine), and arginine dihydrolase tests were negative. No strain emulsified phospholipid agents in egg yolk agar, decomposed 
TABLE 3. Organic substrates utilized by all or none of the strains studied as sole sources of carbon and energy $^{a}$

\begin{tabular}{|c|c|c|}
\hline \multirow{2}{*}{ Class of compounds } & \multicolumn{2}{|l|}{ Organic compounds utilized by: } \\
\hline & All strains & No strain \\
\hline Organic acids (salts) & $\begin{array}{l}\text { Acetate, formate, fumarate, gluconate, } 2 \text {-keto-D- } \\
\text { gluconate, } \alpha \text {-keto-glutarate, glucuronate, glycer- } \\
\text { ate, } 3 \text {-hydroxybutyrate, L-lactate, L-malate, pyru- } \\
\text { vate, succinate }\end{array}$ & $\begin{array}{l}\text { Benzoate, citroconate, } \\
\text { poly- } \beta \text {-hydroxybutyr- } \\
\text { ate, DL-mandelate }\end{array}$ \\
\hline Amino acids (salts) & $\begin{array}{l}\text { L-Alanine, } \beta \text {-alanine, DL- } \alpha \text {-alanine, } 4 \text {-aminobutyr- } \\
\text { ate, L-aspartate, L-glutamate, glycyl-glycine, L- } \\
\text { histidine, L-isoleucine, L-leucine, L-phenylala- } \\
\text { nine, L-proline, L-serine }\end{array}$ & $\begin{array}{l}\text { L-Arginine, L-lysine, L- } \\
\text { methionine, L- } \\
\text { threonine, L-tryptophan }\end{array}$ \\
\hline $\begin{array}{l}\text { Carbohydrates and sugar } \\
\text { derivatives }\end{array}$ & $\begin{array}{l}\text { D-Fructose, D-galactose, D-glucose, maltose, D- } \\
\text { mannose, sucrose, trehalose }\end{array}$ & $\begin{array}{l}\text { D-Arabinose, cellobiose, } \\
\text { cellulose, L-fucose, D- } \\
\text { fucose, 6-deoxy-D-glu- } \\
\text { cose, glycogen, lactose, } \\
\text { raffinose, starch, D-xy- } \\
\text { lose }\end{array}$ \\
\hline Alcohols & Glycerol, D-mannitol, n-propanol, D-sorbitol & \\
\hline $\begin{array}{l}\text { Amines and nitrogenous } \\
\text { compounds }\end{array}$ & Creatin, L-asparagine, L-glutamine, sarcosine & Ethanolamine, triethano- \\
\hline Other compounds & & Dodecan, hexadecan \\
\hline
\end{tabular}

${ }^{a}$ Defined media containing $\mathrm{NH}_{4} \mathrm{Cl}$ as the nitrogen source were used.

Tween 80 , Tween 60 , and Tween 40 , peptonized milk, hydrolyzed casein, gelatin, starch, or cellulose, or depolymerized poly- $\beta$-hydroxybutyric acid granules.

Ribulosebisphosphate carboxylase and phosphoribulokinase were present in autotrophically grown cells and were absent or showed low activity in cells grown on fructose. All 14 strains studied contained only one type of hydrogenase bound to cell membranes that did not reduce pyridine nucleotides but did reduce methylene blue. In autotrophically grown cells average enzyme activities were $1,400 \mathrm{U} / \mathrm{g}$ of crude extract protein and $5,700 \mathrm{U} / \mathrm{g}$ of protein in membrane fractions. All strains but one (Stanier $381^{\mathrm{T}}$ ) formed hydrogenases constitutively, whereas strain Stanier $381^{\mathrm{T}}$ was unique among the 14 strains studied; the hydrogenase of this strain behaved as an inducible enzyme and was only formed when hydrogen was present (35). Fructose-grown cells contained both 6-phosphogluconate dehydratase and phospho-2-keto3-deoxygluconate aldolase (Entner-Doudoroff system) at elevated levels of 120 to $250 \mathrm{U} / \mathrm{g}$ of protein, and this activity decreased to about 10 $\mathrm{U} / \mathrm{g}$ of protein in autotrophically grown cells.

Cells grown anaerobically with glucose and nitrate contained membrane-bound type $b$ and type $c$ cytochromes; no type $a$ cytochrome was detected. The soluble fraction exhibited a reduced-minus-oxidized difference spectrum with peaks at $419,520,620$, and $670 \mathrm{~nm}$, indicative of cytochrome $c d$. In contrast, cells grown autotrophically with $\mathrm{H}_{2}$ as the electron donor and $\mathrm{O}_{2}$ as the electron acceptor had essentially the same cytochrome pattern; however, there was a de- creased concentration of the soluble type $c d$ cytochrome and a type a cytochrome in the membrane fraction. Membrane-bound ubiquinone could be demonstrated. These results are in agreement with data reported previously $(29$, $33,46)$. Cytochrome oxidase and catalase activities were very high.

None of the strains exhibited an ability to grow on thiosulfate as the electron donor instead of hydrogen at $\mathrm{pH} \mathrm{7.0.} \mathrm{No} \mathrm{hydrogen} \mathrm{sulfide} \mathrm{was}$ produced from thiosulfate on triple sugar iron agar slants. Without exception, growth in litmus milk caused a slight alkaline reaction with no detectable proteolytic activity.

Only strain N7 grew in Moeller KCN broth. All strains were susceptible to $25 \mu \mathrm{g}$ of ampicillin per $\mathrm{ml}, 10 \mathrm{U}$ of bacitracin per $\mathrm{ml}, 30 \mu \mathrm{g}$ of kanamycin per $\mathrm{ml}, 30 \mu \mathrm{g}$ of neomycin per $\mathrm{ml}, 30$ $\mu \mathrm{g}$ of novobiocin per $\mathrm{ml}, 300 \mathrm{U}$ of polymyxin $\mathrm{B}$ per $\mathrm{ml}$, and $50 \mu \mathrm{g}$ of tetracycline per $\mathrm{ml}$ and resistant to $300 \mu \mathrm{g}$ of sulfatriad per ml. Only a few of the antibiotics tested discriminated among the strains studied and, therefore, were of taxonomic value (Table 8).

DNA base compositions, DNA-DNA homology, and molecular weights of bacterial genome DNAs. The DNA base compositions of the strains tested ranged from 65 to $67 \mathrm{~mol} \% \mathrm{G}+\mathrm{C}$, as estimated by the thermal denaturation method. The strains were previously characterized by the degree of DNA-DNA binding (duplexing), which ranged from 40 to $100 \%$ binding to the three reference strains studied (Stanier $381^{\mathrm{T}}$, Morris 5 , and N4) (3); the molecular weights of the genome DNAs ranged from $2.5 \times 10^{9}$ to $3.4 \times$ $10^{9}(3)$. 
TABLE 4. Organic substrates utilized by one or more, but not all, of the strains studied ${ }^{a}$

\begin{tabular}{|c|c|c|c|c|c|c|c|c|c|c|c|c|c|c|}
\hline \multirow{3}{*}{ Substrate } & \multicolumn{14}{|c|}{ Utilization by the following strains: $:^{b}$} \\
\hline & \multicolumn{11}{|c|}{ New isolates } & \multirow{2}{*}{$\underset{65^{\mathrm{T}}}{\mathrm{DSM}}$} & \multirow{2}{*}{$\begin{array}{c}\text { DSM } \\
413\end{array}$} & \multirow{2}{*}{$\begin{array}{c}\text { DSM } \\
415\end{array}$} \\
\hline & N1 & $\mathbf{N} 2$ & N3 & N4 & N5 & N6 & N7 & N8 & N9 & N10 & N11 & & & \\
\hline \multicolumn{15}{|l|}{ Organic acids (salts) } \\
\hline L-Ascorbate & - & - & $\mathrm{m}$ & $\mathrm{m}$ & - & m & m & - & - & $\mathrm{m}$ & - & $\mathrm{m}$ & $\mathrm{m}$ & - \\
\hline Citrate & - & $\mathrm{m}$ & $\mathrm{m}$ & m & - & m & - & - & - & - & - & - & - & - \\
\hline D-Galacturonate & - & - & - & - & - & - & - & - & + & + & + & - & + & + \\
\hline Glycolate & + & + & + & + & + & + & + & + & - & - & + & + & + & + \\
\hline Glyoxylate & + & + & + & + & + & + & + & - & $\mathrm{m}$ & $\mathrm{m}$ & + & + & + & + \\
\hline 3-Hydroxybenzoate & + & + & + & + & m & $\mathrm{m}$ & + & + & - & - & - & - & + & + \\
\hline 4-Hydroxybenzoate & + & + & $\mathrm{m}$ & + & - & - & + & + & - & m & + & + & + & + \\
\hline 2-Hydroxybutyrate & - & - & $\mathrm{m}$ & - & - & - & $\mathrm{m}$ & - & - & - & - & $\mathrm{m}$ & - & $\mathrm{m}$ \\
\hline Isobutyrate & + & $\mathrm{m}$ & + & + & + & + & + & + & $\mathrm{m}$ & m & + & + & + & + \\
\hline DL-Iso-citrate & - & - & - & - & -- & - & + & - & + & + & - & - & - & + \\
\hline Malonate & - & - & - & - & - & - & - & - & + & + & - & + & + & + \\
\hline Mesaconate & m & - & - & - & - & - & $\mathrm{m}$ & - & - & - & - & - & + & + \\
\hline Oxalate & $\mathrm{m}$ & m & - & $\mathrm{m}$ & $\mathrm{m}$ & m & - & - & - & - & - & - & - & - \\
\hline Propionate & + & m & $\mathrm{m}$ & $\mathrm{m}$ & $\mathrm{m}$ & m & $\mathrm{m}$ & m & - & - & m & m & $\mathrm{m}$ & $\mathrm{m}$ \\
\hline Suberate & - & - & - & - & - & - & - & + & - & - & + & - & - & - \\
\hline Tartrate & + & + & + & - & + & + & $\mathrm{m}$ & - & - & - & - & + & - & - \\
\hline \multicolumn{15}{|l|}{ Amino acids (salts) } \\
\hline L-Cysteine & - & - & $\mathrm{m}$ & $\mathrm{m}$ & $\mathrm{m}$ & m & - & - & - & - & - & - & - & - \\
\hline Glycine & + & + & + & + & + & + & $\mathrm{m}$ & $\mathrm{m}$ & - & - & - & - & + & + \\
\hline L-Orthinine & - & - & - & - & - & - & - & - & - & - & - & - & $\mathrm{m}$ & $\mathrm{m}$ \\
\hline L-Tyrosine & + & + & - & - & - & - & + & - & + & - & - & + & + & + \\
\hline Urate & + & + & + & + & + & + & + & - & - & - & + & + & + & + \\
\hline L-Valine & - & - & - & $\mathrm{m}$ & - & - & $\mathrm{m}$ & $\mathrm{m}$ & - & - & - & - & + & + \\
\hline \multicolumn{15}{|l|}{ Sugars } \\
\hline L-Arabinose & + & + & + & + & + & + & + & - & + & + & - & $\mathrm{m}$ & + & + \\
\hline D-Ribose & + & + & + & + & + & + & + & - & - & - & - & + & + & + \\
\hline L-Rhamnose & - & - & + & - & - & - & + & - & + & + & - & - & - & - \\
\hline L-Sorbose & $\mathrm{m}$ & $\mathrm{m}$ & - & $\mathrm{m}$ & - & - & - & - & - & - & - & - & - & - \\
\hline D-Tagatose & + & + & + & + & + & + & + & - & - & - & - & - & + & + \\
\hline \multicolumn{15}{|l|}{ Alcohols } \\
\hline Ethanol & + & + & + & + & + & + & + & + & + & - & + & + & + & + \\
\hline Methanol & - & + & - & - & - & - & + & - & - & - & - & + & + & + \\
\hline Phenol & - & - & - & - & + & + & - & - & - & - & - & - & - & - \\
\hline Casein hydrolysate & - & - & + & + & + & + & + & - & + & + & - & + & + & + \\
\hline
\end{tabular}

${ }^{a}$ A defined medium containing $\mathrm{NH}_{4} \mathrm{Cl}$ as the nitrogen source was used.

${ }^{b}+$, Utilized; - , not utilized; $\mathrm{m}$, mutational event.

Computer analysis. Figure 2 shows a dendrogrammatic plot of the relationships among the strains studied, which was drawn from a similarity matrix (Jaccard coefficient).

\section{DISCUSSION}

Isolation of numerous strains of denitrifying hydrogen-oxidizing bacteria from different localities and ecosystems indicated the great adaptability of these organisms. These strains possessed rather versatile metabolic systems and could satisfy their energy demands from (i) organic substrates and molecular oxygen, (ii) organic substrates and nitrate, nitrite, or nitrous oxide, (iii) molecular hydrogen and oxygen, and (iv) molecular hydrogen and nitrate, nitrite, or nitrous oxide. The last system is the basis of the specific epithet of $\boldsymbol{P}$. denitrificans, which refers to the outstanding property of this organism, a distinctive character not found in any other organism.

Our data showed that the strains which we studied are closely related and matched the definition of $P$. denitrificans. The close relationships are based on the DNA base composition, which ranges from 65 to $67 \mathrm{~mol} \% \mathrm{G}+\mathrm{C}$, and on high DNA homology values, as well as on the basic cultural, morphological, cytological, physiological, and biochemical data. The recognition of $\boldsymbol{P}$. denitrificans as a well-delineated, homogenous species (9) is thus confirmed.

In contrast to the finding of Davis et al. (9) that strains ATCC 13543, ATCC $17741^{\mathrm{T}}$ (= Stanier $381^{\mathrm{T}}$ ), and ATCC 19367 (= Morris 5) may represent the same original isolate of $P$. denitrificans, our data provide several characters that differentiate these strains from one another and support the suggestion of Kocur and 
TABLE 5. Nitrogenous compounds utilized by one or more, but not all, of the strains studied as a sole nitrogen source ${ }^{a}$

\begin{tabular}{|c|c|c|c|c|c|c|c|c|c|c|c|c|c|c|}
\hline \multirow{3}{*}{ Substrate } & \multicolumn{14}{|c|}{ Utilization by the following strains: $^{b}$} \\
\hline & \multicolumn{11}{|c|}{ New isolates } & \multirow{2}{*}{$\underset{65^{\mathrm{T}}}{\mathrm{DSM}}$} & \multirow{2}{*}{$\underset{413}{\text { DSM }}$} & \multirow{2}{*}{$\begin{array}{c}\text { DSM } \\
415\end{array}$} \\
\hline & N1 & N2 & N3 & N4 & N5 & N6 & N7 & N8 & N9 & N10 & N11 & & & \\
\hline$\beta$-Alanine & + & + & + & + & + & + & + & + & + & + & - & + & + & + \\
\hline L-Aspartate & + & + & + & + & + & + & + & + & - & - & + & + & + & + \\
\hline L-Asparagine & \pm & \pm & \pm & \pm & \pm & \pm & + & + & - & - & - & - & - & - \\
\hline L-Lysine & $\overline{+}$ & $\overline{+}$ & $\bar{t}$ & $\bar{t}$ & $\bar{t}$ & $\overline{+}$ & + & + & \pm & \pm & \pm & + & \pm & \pm \\
\hline L-Ornithine & $\mathrm{m}$ & $\mathrm{m}$ & - & \pm & $\mathrm{m}$ & $\mathrm{m}$ & - & \pm & $\mathrm{m}$ & m & $\mathrm{m}$ & m & $\mathrm{m}$ & $\mathrm{m}$ \\
\hline Urate & + & + & + & + & + & + & + & m & $\mathrm{m}$ & $\mathrm{m}$ & + & + & + & + \\
\hline Potassium nitrite & + & + & + & + & + & + & + & - & \pm & \pm & + & + & + & + \\
\hline
\end{tabular}

${ }^{a}$ A nitrogen-free defined medium containing fructose as the growth substrate and $1 \mathrm{~g}$ of the tested nitrogen compound per liter was used.

${ }^{b}+$, Good growth; \pm , scanty growth; - , no growth; m, mutational event.

Martinec (25) that they should be dealt with as distinct strains. This notion received further support by the detection of plasmids in three reference strains of $P$. denitrificans (14a). Strains DSM $65^{\mathrm{T}}$, DSM 413, and DSM 415 contain large plasmids having molecular weights of more than $300 \times 10^{6}$. These plasmids are apparently not identical. The type strain, strain DSM $65^{\mathrm{T}}$, harbors an additional small plasmid having a molecular weight of $50 \times 10^{6}$.

On the basis of a computer analysis of 235 characters, the strains which we examined belong to four subgroups (Fig. 2). Subgroup I includes strains N1 through N6, with similarities of $74 \%$ or more; subgroup II includes strains N7, Morris 5, Vogt 11 , and Stanier $381^{\mathrm{T}}$, with a similarity of $75 \%$; subgroup III includes strains N8 and N11, with a similarity of $76 \%$; and subgroup VI includes strains $\mathrm{N} 9$ and N10, with a similarity of $88 \%$. The degrees of similarity (Jaccard coefficients) for these subgroups were $68 \%$ for subgroups II and III, $65 \%$ for subgroups I, II, and III, and $62.5 \%$ for all subgroups simultaneously. This subgrouping is in agreement with that obtained by DNA-DNA reassociation kinetics (3).

Taxonomic considerations. As stated above and as has been pointed out previously by both Baird-Parker (4) and Rosypal et al. (40), this gram-negative, nonsporeforming, nonpigmented, short, rod-shaped bacterium (coccobacillus) cannot be assigned to either the genus Micrococ-

TABLE 6. Effect of yeast autolysate on autotrophic growth of $\boldsymbol{P}$. denitrificans strains ${ }^{a}$

\begin{tabular}{|c|c|c|c|c|}
\hline \multirow{3}{*}{ Strain } & \multicolumn{4}{|c|}{ Doubling times (h) with the following electron acceptors: } \\
\hline & \multicolumn{2}{|c|}{ Oxygen } & \multicolumn{2}{|c|}{ Nitrate } \\
\hline & $\begin{array}{c}\text { With } \\
\text { yeast extract }\end{array}$ & $\begin{array}{c}\text { Without } \\
\text { yeast extract }\end{array}$ & $\begin{array}{c}\text { With } \\
\text { yeast extract }\end{array}$ & $\begin{array}{c}\text { Without } \\
\text { yeast extract }\end{array}$ \\
\hline N1 & 5.0 & 4.7 & 29 & 20 \\
\hline N2 & 5.3 & 4.5 & 22 & 17 \\
\hline N3 & 5.0 & 4.2 & 16 & 21 \\
\hline N4 & 4.3 & 3.9 & 42 & 8 \\
\hline N5 & 4.6 & 4.5 & 59 & 31 \\
\hline N6 & 4.6 & 3.9 & 36 & 24 \\
\hline N7 & 3.1 & 4.1 & 15 & 15 \\
\hline N8 & 50 & 40 & 26 & 21 \\
\hline N9 & 4.1 & 3.8 & 13 & 12 \\
\hline N10 & 10 & 16 & 15 & 20 \\
\hline N11 & 7.3 & 8.8 & 18 & 20 \\
\hline $\operatorname{DSM} 65^{\mathrm{T}}$ & 3.7 & 4.1 & 41 & 5 \\
\hline DSM 413 & 4.9 & 4.4 & 22 & 22 \\
\hline DSM 415 & 4.7 & 4.8 & 21 & 18 \\
\hline
\end{tabular}

${ }^{a}$ Cultures were grown in $300-\mathrm{ml}$ Erlenmeyer flasks containing $40 \mathrm{ml}$ of SM medium supplemented with bicarbonate, shaken in a $30^{\circ} \mathrm{C}$ water bath and flushed with a gas mixture containing $\mathrm{H}_{2}, \mathrm{CO}_{2}$, and $\mathrm{O}_{2}(80: 10: 10$, $\mathrm{vol} / \mathrm{vol}$ ) for aerobic growth. For anaerobic growth, the same medium was supplemented with $1 \%$ (wt/vol) $\mathrm{KNO}_{3}$, and the gas mixture contained $\mathrm{H}_{2}$ and $\mathrm{CO}_{2}(90: 10$, vol/vol). Growth was measured turbidimetrically.

${ }^{b}$ Yeast extract $(0.005 \%$, wt/vol) was added. 
TABLE 7. Tolerance of $\boldsymbol{P}$. denitrificans strains to oxygen under autotrophic conditions and to salt under heterotrophic conditions

\begin{tabular}{lcc}
\hline Strain & $\begin{array}{c}\text { Maximum } \\
\text { oxygen concn } \\
(\%, \text { volkvol })^{a}\end{array}$ & $\begin{array}{c}\text { Maximum } \\
\text { salt concn } \\
(\%, \text { wt/vol) }\end{array}$ \\
\hline N1 & 40 & 4 \\
N2 & 40 & 6 \\
N3 & 45 & 6 \\
N4 & 65 & 4 \\
N5 & 45 & 4 \\
N6 & 45 & 5 \\
N7 & 45 & 4 \\
N8 & 25 & 4 \\
N9 & 25 & 4 \\
N10 & 25 & 7 \\
N11 & 40 & 4 \\
DSM 65 & 30 & 7 \\
DSM 413 & 40 & 3 \\
DSM 415 & 40 & 3 \\
\hline
\end{tabular}

${ }^{a}$ Cells were grown in SM medium containing bicarbonate under a gas mixture composed of $5 \% \mathrm{CO}_{2}$ and different concentrations of $\mathrm{O}_{2}$ and $\mathrm{H}_{2}$ (intervals of $5 \%$ ). The values indicate the highest oxygen concentrations under which growth occurred within 5 days. $\mathrm{H}_{2}$ served as a balance.

${ }^{b}$ Cells were grown in nutrient broth supplemented with sodium chloride, and growth was followed turbidimetrically daily for 1 week. The values indicate the highest $\mathrm{NaCl}$ concentrations in which growth occurred within 7 days.

cus or the genus Staphylococcus, both of which are gram positive. It seems likely that the type species of the genus Paracoccus is closely related to some facultatively chemolithoautotrophic species in the genera Alcaligenes and Pseudomonas and resembles at least the facultatively organotrophic species of the genus Thiobacillus (11), as well as members of the genera Neisseria and Moraxella (9), "Acinetobacter cerificans" (12), and "Methylococcus capsulatus" (26); e.g., it shares the following characters with the peritrichous species Alcaligenes eutrophus Davis: gram negative, neither sporulation nor pigmentation, growth on hydrogen plus carbon dioxide, accumulation of poly- $\beta$-hydroxybutyric acid, growth and denitrification in organic media, inability to use arginine either aerobically or anaerobically as a carbon or energy source, strictly aerobic, and DNA base composition ranging from 66 to $67 \mathrm{~mol} \% \mathrm{G}+\mathrm{C}$; furthermore, the cells of $A$. eutrophus become almost spherical and nonflagellated in the stationary phase of growth. Paracoccus denitrificans shares with Pseudomonas facilis, Pseudomonas flava, Pseudomonas pseudoflava, Pseudomonas palleronii, and Pseudomonas saccharophila the following properties: gram negative, nonsporeforming, growth on hydrogen and carbon dioxide, accumulation of poly- $\beta$-hydroxybutyric
TABLE 8. Antibiotic susceptibility patterns of $P$. denitrificans strains

\begin{tabular}{llllllll}
\hline \multirow{2}{*}{ Strain } & \multicolumn{7}{c}{ Inhibitor $^{a}$} \\
\cline { 2 - 8 } & Ca & Ch & Cl & Er & Ox & Pe & St \\
\hline DSM 65 & + & + & - & \pm & + & + & - \\
DSM 413 & + & + & + & \pm & + & - & \pm \\
DSM 415 & + & + & + & \pm & + & - & - \\
N1 & + & + & - & + & + & \pm & - \\
N2 & + & + & - & - & + & + & - \\
N3 & + & + & - & \pm & + & \pm & - \\
N4 & + & + & - & \pm & + & \pm & \pm \\
N5 & + & + & - & - & + & + & \pm \\
N6 & + & + & - & - & + & + & - \\
N7 & + & - & - & - & + & - & \pm \\
N8 & - & + & - & - & - & - & \pm \\
N9 & + & + & - & - & - & - & \pm \\
N10 & + & + & - & - & - & - & \pm \\
N11 & + & + & - & \pm & + & - & \pm \\
\hline
\end{tabular}

${ }^{a}$ Abbreviations: Ca, carbenicillin $(100 \mu \mathrm{g} /$ disk $)$; Ch, chloramphenicol (50 $\mu \mathrm{g} / \mathrm{disk}) ; \mathrm{Cl}$, cloxacillin $(5 \mu \mathrm{g} /$ disk); Er, erythromycin (15 $\mu$ g/disk); Ox, oxytetracycline $(30 \mu \mathrm{g} /$ disk); Pe, penicillin G (10 U/disk); St, streptomycin $(25 \mu \mathrm{g} / \mathrm{disk})$. The zones of inhibition were measured from the edges of susceptibility disks (Oxoid) used to the edges of clear zones. -, Resistance (inhibition zone, $<2 \mathrm{~mm}$ ); \pm , weak susceptibility (inhibition zone, 2 to $5 \mathrm{~mm}$ ); + , full susceptibility (inhibition zone, $>5 \mathrm{~mm}$ ).

acid, growth on a wide spectrum of organic substrates, inability to use arginine aerobically or anaerobically as a carbon or energy source, absence of arginine dihydrolase (10), obligately respiratory, inability to grow at $41^{\circ} \mathrm{C}$, no growth factor requirements, and identical DNA base

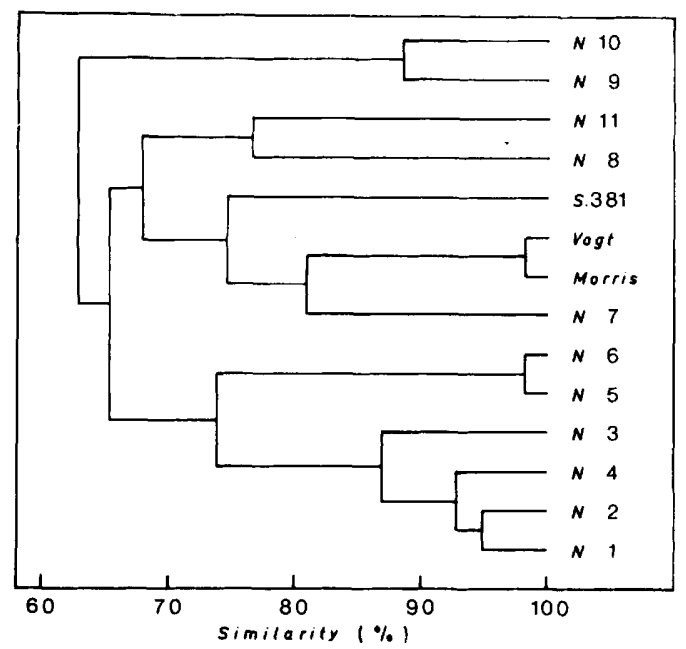

FIG. 2. Dendrogram showing the arrangement of medium-sized strains studied after complete linkage clustering. Similarities were determined by using the Jaccard coefficient and the product-moment correlation coefficient, as modified for binary data (40). 
compositions (64 to $69 \mathrm{~mol} \% \mathrm{G}+\mathrm{C}$ ). In many respects, $P$. denitrificans resembles Thiobacillus novellus, which is a gram-negative, nonmotile, nonpigmented, short, rod-shaped or coccoidal bacterium, is strictly respiratory, can grow autotrophically with $\mathrm{CO}_{2}$ as the carbon source, and has a DNA base composition of 66 to $68 \mathrm{~mol} \%$ $\mathrm{G}+\mathrm{C}(20)$. A relationship with the thiobacilli is indicated by the fact that $P$. denitrificans can grow on thiosulfate at $\mathrm{pH} 8.0$ under strictly lithoautotrophic conditions (14). Neisseria and Moraxella (9) differ from $P$. denitrificans in DNA base composition ( 40 to $46 \mathrm{~mol} \% \mathrm{G}+\mathrm{C}$ in Moraxella and about $50 \mathrm{~mol} \% \mathrm{G}+\mathrm{C}$ in Neisseria). Kocur et al. (26) assumed that both $P$. denitrificans and Paracoccus halodenitrificans are morphologically and biochemically similar to the gram-negative cocci described as "Acinetobacter cerificans" (12) and to Methylococcus capsulatus (13).

On the basis of our data, we propose the following formal taxonomic description.

Amended description of Paracoccus denitrificans. Paracoccus denitrificans (Beijerinck) Davis 1969, 384. (Micrococcus denitrificans Beijerinck and Minkman 1910, 54; Pa. ra. coc'cus. Gr. prep. para like, coccus a grain, berry; M.L. masc. n. Paracoccus like a coccus. de. ni. tri'fi.cans. L. prep. de away from; L. n. nitrum soda; M. L. n. nitrum nitrate; M. L. v. denitrifo denitrify; M. L. part. adj. denitrificans denitrifying).

Cell morphology and cytological characters. Nonpigmented, immotile, nonflagellated, short, rod-shaped cells (coccobacilli) with average dimensions of 0.6 by $0.85 \mu \mathrm{m}$ in stationary phase and 0.8 by $1.2 \mu \mathrm{m}$ in exponential growth phase. No spores or resting bodies are formed. Oneplane transverse fission produces equal daughter cells. Cells occur singly and in pairs but never in aggregates and accumulate granules of poly- $\beta$ hydroxybutyric acid, glycogen-like material, and poly-phosphate as intracellular reserve material. Gram negative and non-acid fast.

The $\mathrm{G}+\mathrm{C}$ content of the DNA is 65 to 67 mol\%. The molecular weight of the bacterial genome DNA ranges from $2.3 \times 10^{9}$ to $3.4 \times$ $10^{9}$.

Cultural properties. Agar colonies are circular, smooth, glistening, semitranslucent, creamy with a soft consistency, and turn white and opaque in nitrogen-deficient media. Liquid cultures are turbid without pellicles.

Growth substrates. Of 100 organic compounds tested, 41 were utlized, 28 were not utilized, and the rest were utilized by one or more of the strains. L-Alanine, L-arginine, L-phenylalanine, L-proline, urea, ammonium chloride, and potassium nitrate serve as universal nitrogen sources, but nitrogen fixation does not occur. Growth factors, activators, or vitamins are not required. Utilize molecular hydrogen, but not carbon monoxide, ferrous iron, elemental sulfur, or reduced sulfur compounds at $\mathrm{pH} 7.0$ as electron donors for autotrophic growth.

Biochemical and physiological features. Good growth in media with pH values of 6 to 10 and at temperatures of 8 to $40^{\circ} \mathrm{C}$. Optimum growth in media at $\mathrm{pH} 7.6$ and $36^{\circ} \mathrm{C}$. Metabolism respiratory, never fermentative. Tolerant to oxygen concentrations up to $65 \%$ ( $\mathrm{vol} / \mathrm{vol})$ under autotrophic growth conditions. Tolerant to about $7 \%$ (wt/vol) $\mathrm{NaCl}$. Free oxygen, nitrate, nitrite, or nitrous oxide serves as a terminal electron acceptor. Autotrophic denitrification, as well as organotrophic denitrification with several organic compounds. Dissimilation of aromatic compounds via protocatechuate by ortho cleavage. The following tests were negative: methyl red, Voges-Proskauer, indole formation, urease activity, decarboxylation of L-amino acids (arginine, lysine, ornithine), arginine dihydrolase activity, phospholipase (lecithinase) activity, lipase activity on Tween 80 , Tween 60 , and Tween 40, proteinase activity on both vitaminfree casein and milk casein, gelatin liquefaction, starch and cellulose hydrolysis, exogenous poly$\beta$-hydroxybutyric acid depolymerase activity, as well as $\mathrm{H}_{2} \mathrm{~S}$ production. Hydrogenase is exclusively membrane bound and constitutive except in strain Stanier $381^{\mathrm{T}}$, where it is inducible. Phosphoribulokinase and ribulosebisphosphate carboxylase, the key enzymes of the Calvin cycle, are inducible. Fructose-grown cells contain both 6-phosphogluconate dehydratase and phospho-2-keto-3-deoxygluconate aldolase at elevated levels and lack 6-phosphofructokinase and fructose bisphosphate aldolase. The membrane fraction of cells grown anaerobically with nitrate contains type $b$ and $c$ cytochromes but not type $a$ cytochromes, and the soluble fraction includes a type $c d$ cytochrome; the membrane fraction of aerobically grown cells contains type $a, b$, and $c$ cytochromes, and the soluble fraction contains only a few type $c d$ cytochromes. Membrane-bound ubiquinone. Terminal respiratory enzymes, as well as oxidase and catalase, are very active. Slight alkaline reaction in litmus milk. Only one strain, strain N7 (= DSM 1406), could grow in Moeller KCN broth.

Susceptibility to antibiotics. Tolerant to $300 \mu \mathrm{g}$ of sulfatriad per ml but not to $25 \mu \mathrm{g}$ of ampicillin per $\mathrm{ml}, 10 \mathrm{U}$ of bacitracin per $\mathrm{ml}, 30 \mu \mathrm{g}$ of kanamycin per $\mathrm{ml}, 30 \mu \mathrm{g}$ of neomycin per $\mathrm{ml}, 30$ $\mu \mathrm{g}$ of novobiocin per $\mathrm{ml}, 300 \mathrm{U}$ of polymyxin B per $\mathrm{ml}$, or $50 \mu \mathrm{g}$ of tetracycline per $\mathrm{ml}$.

Habitat. Presumably widely distributed in soil, mud, animal manure, sewage, and sludge.

Type strain. ATCC $17741^{\mathrm{T}}\left(=\mathrm{DSM} 65^{\mathrm{T}}\right)$.

Type species of the genus Paracoccus (Beijer- 
inck) Davis.

Six of the newly isolated strains have been deposited with the Deutsche Sammlung von Mikroorganismen under the following numbers: DSM 1403 (= strain N1), DSM 1404 (= strain N4), DSM 1405 (= strain N5), DSM 1406 (= strain N7), DSM 1407 (= strain N10), and DSM 1408 ( = strain N11).

\section{ACKNOWLEDGMENTS}

We thank F. Mayer, D. Claus, Irmelin Probst, B. Bowien, W. Hunger, K. Malik, Angelika Opitz, and R. Opitz for their kind and generous help in various stages of this work.

T.-H.N. received financial support from the Egyptian Government.

\section{LITERATURE CITED}

1. Abdelal, A. T. H., and H. G. Schlegel. 1974. Purification and regulatory properties of phosphoribulokinase from Hydrogenomonas eutropha $\mathrm{H}$ 16. Biochem. J. 139:481489.

2. Aggag, M., and H. G. Schlegel. 1973. Studies on grampositive hydrogen bacterium, Nocardia opaca strain $1 \mathrm{~b}$. I. Description and physiological characterization. Arch. Mikrobiol. 88:299-318.

3. Auling, G., M. Dittbrenner, M. Maarzahl, T. Nokhal, and M. Reh. 1980. Deoxyribonucleic acid relationships among hydrogen-oxidizing strains of the genera Pseudomonas, Alcaligenes, and Paracoccus. Int. J. Syst. Bacteriol. 30:123-128.

4. Baird-Parker, A. C. 1965. The classification of staphylococci and micrococci from world-wide sources. J. Gen. Microbiol. 38:363-387.

5. Beijerinck, M. W., and D. C. J. Minkman. 1910. Bildung und Verbrauch von Stickoxydul durch Bakterien. Zentralbl. Bakteriol. Parasitenkd. Infektionskr. Hyg. Abt. 2 25:30-63.

6. Bowien, B., F. Mayer, G. A. Codd, and H. G. Schlegel. 1976. Purification, some properties and quaternary structure of the D-ribulose 1,5-diphosphate carboxylase of Alcaligenes eutrophus. Arch. Microbiol. 110:157-166.

7. Claus, D., and C. Schaab-Engels. 1977. Catalogue of strains. German collection of microorganisms. Gesellschaft für Strahlen und Umweltforschung $\mathrm{mbH}$, München.

8. Cowan, S. T. 1974. Cowan and Steel's manual for the identification of medical bacteria, 2nd ed. Cambridge University Press, Cambridge, England.

9. Davis, D. H., M. Doudoroff, R. Y. Stanier, and M. Mandel. 1969. Proposal to reject the genus Hydrogenomonas: taxonomic implications. Int. J. Syst. Bacteriol. 19:375390 .

10. Davis, D. H., R. Y. Stanier, M. Doudoroff, and M. Mandel. 1970. Taxonomic studies on some Gram-negative polarly flagellated "hydrogen bacteria" and related species. Arch. Mikrobiol. 70:1-13.

11. Doudoroff, M. 1974. Genus Paracoccus Davis in Davis, Doudoroff, Stanier and Mandel 1969, 384, p. 438-440. In R. E. Buchanan and N. E. Gibbons (ed.), Bergey's manual of determinative bacteriology, 8 th ed. The Williams \& Wilkins Co., Baltimore.

12. Finnerty, W. R., E. Hawtrey, and R. E. Kallio. 1962. Alkane-oxidizing micrococci. Z. Allg. Mikrobiol. 2:169_ 177.

13. Foster, J. W., and R. H. Davis. 1966. A methane-dependent coccus, with notes on classification and nomenclature of obligate, methane-utilizing bacteria. J. Bacteriol. 91:1924-1931.

14. Friedrich, C. G., and G. Mitrenga. 1981. Oxidation of thiosulfate by Paracoccus denitrificans and other hydrogen bacteria. FEMS Microbiol. Lett. 10:209-212.

14a.Gerstenberg, C., B. Friedrich, and H. G. Schlegel. 1982.
Physical evidence for plasmids in autotrophic, especially hydrogen-oxidizing bacteria. Arch. Microbiol. 133:90-96.

15. Gottschalk, G. 1964 . Verwertung von Fructose durch Hydrogenomonas H 16. II. Cryptisches Verhalten gegenüber Glucose. Arch. Mikrobiol. 49:96-102.

16. Gottschalk, G., U. Eberhardt, and H. G. Schlegel. 1964. Verwertung von Fructose durch Hydrogenomonas H 16 (I.). Arch. Mikrobiol. 48:95-108.

17. Holding, A. J., and J. G. Collee. 1971. Routine biochemical tests, p. 1-32. In J. R. Norris and D. W. Ribbons (ed.), Methods in microbiology, vol. 6A. Academic Press, Inc., London.

18. Hugh, R., and E. Leifson. 1955. The taxonomic significance of fermentative versus oxidative metabolism of carbohydrates by various gram-negative bacteria. J. Bacteriol. 66:24-26.

19. Jaccard, P. 1908. Nouvelles recherches sur la distribution florale. Bull. Soc. Vaudoise Sci. Nat. 44:223-270.

20. Jackson, J. F., D. J. W. Moriarty, and D. J. D. Nicholas. 1968. Deoxyribonucleic acid base composition and taxonomy of thiobacilli and some nitrifying bacteria. J. Gen. Microbiol. 53:53-60.

21. John, P., and F. R. Whatley. 1975. Paracoccus denitrifcans and evolutionary origin of the mitochondrion. Nature (London) 254:495-498.

22. Jüttner, R.-R., R. M. Lafferty, and H. J. Knackmuss. 1975. A simple method for the determination of poly- $\beta$ hydroxybutyric acid in microbial biomass. Eur. J. App. Microbiol. 1:233-237.

23. Klein, H. P., and M. Doudoroff. 1950. The mutation of Pseudomonas putrefaciens to glucose utilization and its enzymatic basis. J. Bacteriol. 59:739-750.

24. Kluyver, A. J. 1956. Life's flexibility; microbial adaptation, p. 93-129. In A. J. Kluyver and C. B. van Niel (ed.), The microbe's contribution to biology. Harvard University Press, Cambridge, Mass.

25. Kocur, M., and T. Martinec. 1962. A taxonomic study of the genus Micrococcus. Folia Fac. Sci. Univ. Purkynianae Brunensis Czech. 3:78-110.

26. Kocur, M., T. Martinec, and K. Mazanec. 1968. Fine structure of Micrococcus denitrificans and $M$. halodenitrificans in relation to their taxonomy. Antonie van Leeuwenhoek J. Microbiol. Serol. 34:19-26.

27. Kovacs, N. 1956. Identification of Pseudomonas pyocyanea by the oxidase reaction. Nature (London) 178:703.

28. Kröger, A., V. Dadak, M. Klingenberg, and F. Diemer. 1971. On the role of quinones in bacterial electron transport. Differential roles of ubiquinone and menaquinone in Proteus rettgeri. Eur. J. Biochem. 21:322-333.

29. Lam, Y., and D. J. D. Nicholas. 1969. Aerobic and anaerobic respiration in Micrococcus denitrificans. Biochim. Biophys. Acta 172:450-461.

30. Lance, G. N., and W. T. Williams. 1967. A general theory of classificatory sorting strategies. I. Hierarchical system. Comput. J. 9:373-380.

31. Lowry, O. H., N. J. Rosebrough, A. L. Farr, and R. J. Randall. 1951. Protein measurement with the Folin phenol reagent. J. Biol. Chem. 193:265-275.

32. Mandel, M., and J. Marmur. 1968. Use of ultraviolet absorbance temperature profile for determining the guanine plus cytosine content of DNA. Methods Enzymol. 12B:195-206.

33. Newton, N. 1969. The two-haem nitrate reductase of Micrococcus denitrificans. Biochim. Biophys. Acta 185:316-331.

34. Nokhal, T.-H., and F. Mayer. 1979. Structural analysis of four strains of Paracoccus denitrificans. Antonie van Leeuwenhoek J. Microbiol. Serol. 45:185-197.

35. Nokhal, T.-H., and H. G. Schlegel. 1980. The regulation of hydrogenase formation as a differentiating character of strains of Paracoccus denitrificans. Antonie van Leeuwenhoek J. Microbiol. Serol. 46:143-155.

36. Owen, R. J., L. R. Hill, and S. P. Lapage. 1969. Determination of DNA base composition from melting profiles in dilute buffer. Biopolymers 7:503-516. 
37. Pfennig, N. 1974. Rhodopseudomonas globiformis, sp. n., a new species of the Rhodospirillaceae. Arch. Microbiol. 100:197-206.

38. Pitt, T. L., and D. Dey. 1970. A method for the detection of gelatinase production by bacteria. J. Appl. Bacteriol. 33:687-691.

39. Pleva, V., and M. Kocur. 1963. Electron microscopy of the genera Micrococcus and Staphylococcus. Publ. Fac. Sci. Univ. J. E. Purkyne Brno K30:443-444.

40. Rosypal, S., A. Rosypalova, and J. Horels. 1966. The classification of micrococci and staphylococci based on their DNA base composition and Adansonian analysis. $\mathbf{J}$. Gen. Microbiol. 44:281-292.

41. Schäffer, J. B. 1979. Beschreibung and Benutzeranleitung des Wishartschen Clusteranalyse-Pakets. Gesellschaft Strahlen- Umweltforsch. Bericht Md. 295:1-176.

42. Schink, B., and H. G. Schlegel. 1978. Hydrogen metabolism in aerobic hydrogen-oxidizing bacteria. Biochemie 60:297-305.

43. Schlegel, H. G., H. Kaltwasser, and G. Gottschalk. 1961. Ein Submersverfahren zur Kultur wasserstoff-oxydierender Bakterien: wachstumsphysiologische Untersuchungen. Arch. Mikrobiol. 38:209-222.

44. Schmidt, K., S. L. Jensen, and H. G. Schlegel. 1963. Die Carotinoide der Thiorhodaceae. I. Okenon als Hauptcarotinoid von Chromatium okenii Perty. Arch. Mikrobiol. 46:117-126.

45. Schneider, K., and H. G. Schlegel. 1977. Localization and stability of hydrogenases from aerobic hydrogen bacteria. Arch. Microbiol. 112:229-238.

46. Scholes, P. B., and L. Smith. 1968. Composition and properties of the membrane-bound respiratory chain system of Micrococcus denitrificans. Biochim. Biophys. Acta 153:363-375.

47. Shilo, M., and R. Y. Stanier. 1957. The utilization of tartaric acids by Pseudomonas. J. Gen. Microbiol. 16:482-490
48. Sierra, G. 1957. A simple method for the detection of lipolytic activity of micro-organisms and some observations on the influence of the contact between cells and fatty substrates. Antonie van Leeuwenhoek J. Microbiol. Serol. 23:15-22.

49. Sim, E., and R. B. Sim. 1979. Hydrodynamic parameters of the detergent-solubilised hydrogenase from Paracoccus denitrificans. Eur. J. Biochem. 97:119-126.

50. Sim, E., and P. M. Vignais. 1978. Hydrogenase activity in Paracoccus denitrificans. Partial purification and interaction with the electron transport chain. Biochemie 60:307314.

51. Skerman, V. B. D. 1967. A guide to the identification of the genera of bacteria, 2nd ed. The Williams \& Wilkins Co., Baltimore.

52. Skinner, F. A. 1960. The isolation of anaerobic cellulosedecomposing bacteria from soil. J. Gen. Microbiol. 22:539-554.

53. Sneath, P. H. A. 1957 . Some thoughts on bacterial classification. J. Gen. Microbiol. 17:184-200.

54. Stanier, R. Y., N. J. Palleroni, and M. Doudoroff. 1966. The aerobic pseudomonads: a taxonomic study. J. Gen. Microbiol. 43:159-271.

55. Verhoeven, W. 1957. Micrococcus denitrificans Beijerinck, 1910, emend. Sijderius, 1946, p. 463. In R. S. Breed, E. G. D. Murray, and N. R. Smith (ed.), Bergey's manual of determinative bacteriology, 7 th ed. The Williams \& Wilkins Co., Baltimore.

56. Verhoeven, W., A. L. Koster, and M. C. A. van Nievelt. 1954. Studies on true dissimilatory nitrate reduction. IIJ Micrococcus denitrificans Beijerinck, a bacterium capable of using molecular hydrogen in denitrification. Antonie van Leeuwenhoek J. Microbiol. Serol. 20:273-284.

57. Vogt, M. 1965. Wachstumsphysiologische Untersuchungen an Micrococcus denitrificans Beij. Arch. Mikrobiol. 50:256-281. 